\title{
Association of Long-Term Pesticide Exposure and Biologic Parameters in Female Farm Workers in Tanzania: A Cross Sectional Study
}

\author{
Wilbert Bunini Manyilizu ${ }^{1, *}$, Robinson Hammerton Mdegela ${ }^{1}$, Rudovick Kazwala ${ }^{1}$, \\ Hezron Nonga ${ }^{1}$, Mette Muller ${ }^{2}$, Elisabeth Lie ${ }^{2}$, Eystein Skjerve ${ }^{2}$ and Jan Ludvig Lyche ${ }^{2}$ \\ 1 Department of Veterinary Medicine and Public Health, Sokoine University of Agriculture, P. O. Box 3021, \\ Morogoro 023, Tanzania; rmdegela2012@gmail.com (R.H.M.); kazwala@gmail.com (R.K.); \\ nongahezron@yahoo.co.uk (H.N.) \\ 2 Department of Food Safety and Infection Biology, Norwegian University of Life Sciences, P. O. Box 8146, \\ Oslo 454, Norway; mette.helen.bjorge.muller@nmbu.no (M.M.); elisabeth.lie@niva.no (E.L.); \\ eystein.skjerve@nmbu.no (E.S.); jan.l.lyche@nmbu.no (J.L.L.) \\ * Correspondence: wmanyilizu@gmail.com or wbmanyilizu@mzumbe.ac.tz; Tel.: +255-767-567-914; \\ Fax: +255-232-604-382
}

Academic Editor: Christos A. Damalas

Received: 6 April 2016; Accepted: 20 September 2016; Published: 29 September 2016

\begin{abstract}
The study aimed to assess the association of long-term pesticide exposure ( $\geq 5$ years) with hematological, serum biochemical parameters and acetylcholinesterase activity in farm workers. These pesticides included organophosphorus pesticides, carbamates, pyrethroids, dithiocarbamates, and other pesticides such as endosulfan. Applying a cross-sectional study design, 69 females from a pesticide-exposed farm population and 30 females from a district not using pesticides (reference group) were studied. The mean red cell corpuscular volume and hematocrit values were significantly lower $(74.7 \pm 9.1 \mathrm{fl} ; 95 \%$ CI $72.5-76.9$ and $32.0 \% \pm 4.6 \%$; 95\% CI 30.9-33.1, respectively) in the exposed compared to the reference group, whereas mean corpuscular hemoglobin concentration and platelets were significantly higher $(37.4 \pm 3.8 \mathrm{~g} / \mathrm{dL} ; 95 \% \mathrm{CI} 36.5-38.3$ and $374.1 \pm 95.3 / \mathrm{L} ; 95 \%$ CI 351.2-396.9, respectively) in the exposed compared to the reference group. Mean serum glutamic oxaloacetate transaminase (20.7 $\pm 8.9 \mathrm{U} / \mathrm{L} ; 95 \%$ CI 18.5-22.9) and creatinine $(83.9 \pm 6.6 \mu \mathrm{mol} / \mathrm{L} ; 95 \% \mathrm{CI}$ 82.3-85.5) were significantly higher in the exposed compared to the reference group. A higher mean esterase activity (AChE $0.6 \pm 0.2 \mathrm{mM} / \mathrm{min} / \mathrm{mg}$ protein; $95 \% \mathrm{CI}$ 0.56-0.7; BChE $0.9 \pm 0.4 \mathrm{mM} / \mathrm{min} / \mathrm{mg}$ protein; $95 \%$ CI 0.9-1.1) was noted in the exposed group. Regression models suggest that occupational exposure $(p<0.001)$ could be a predictor of esterase (AChE and BChE) activity and biochemical changes ( $\beta=0.4,95 \%$ CI: $0.3-0.5 ; \beta=0.7,95 \%$ CI: 0.6-0.9, respectively). Long-term pesticide exposure affects the hemato-biochemical and esterase responses, establishing the need for further studies.
\end{abstract}

Keywords: pesticides; hematological; biochemical; acetylcholine esterase activity; effects

\section{Introduction}

Agriculture is the economic backbone of Tanzania, providing $80 \%$ of the country's employment and contributing to approximately $26 \%$ of the National Gross Domestic Product [1]. The use of pesticides in agricultural production is necessary in order to increase crop yield and to minimize post-harvest losses. A substantial increase in pesticide use has been documented since the 1990s [2]. A report about trade and utilization of pesticides in Tanzania [3] showed that between 2000 and 2003, the import of pesticides increased from 500 to 2500 tons; by 2006, 682 different types of pesticides were 
registered, including endosulfan and dieldrin, which are restricted by the Stockholm Convention due to their environmental persistence and toxic potential [4].

Use of pesticides has led to an increase in human exposure, which has been associated with acute morbidities [4,5] and mortalities. This is particularly true in developing countries [5,6], where there are poor regulations, low enforcement, difficulties in accessing information, and a lack of surveillance systems and training. Reports from African countries have shown that farm workers use pesticides with low awareness of safe handling, utilization, and protection [7]. A high degree of misuse has been documented, including over- and under-dosing, mixing of different pesticides, dangerous storage of pesticides, poor spraying equipment, and poor use of personal protective gear [8]. Such misuse of pesticides has been associated with adverse health effects among farm workers [9-12]. Most studies report acute health effects on highly exposed groups such as sprayers [9]; however, available data on potential adverse effects of long-term and frequent exposure to multiple pesticides are limited [10-13].

Exposure to pesticides has been associated with central nervous, reproductive, and immune system disorders and cancers [14-29]. Since modern pesticides are rapidly cleared from the body, it is necessary to use relevant biomarkers to indicate exposure and effects.

Acetylcholinesterase (AChE) is a useful biomarker as it provides an integrated measurement of the overall neurotoxic risk of bioavailable contaminants including other environmental and occupational chemicals than organophosphates (OPs) and carbamates [30]. For example, it is reported that AChE can be affected by pyrethroid and triazine pesticides and also heavy metals like mercury, lead, cadmium, and copper. Despite several limitations, such as wide inter-individual and intra-individual variation [31], the AChE test is a useful biomarker in assessing both exposure and effects of OPs and carbamates [32]. Also, its inhibition is more sensitive than butyrylcholinesterase (BChE) in long-term exposure to OPs due to the lower recovery rate compared to BChE. This follows a cumulative inhibitory effect on AChE activity [30,33]. However, for pesticides, which do not affect AChE activity, there are no specific biomarkers of effect established.

Routine blood tests are part of a full clinical examination and are interpreted in conjunction with clinical symptoms for diagnosis of disease. Previous studies have reported associations between long-term, low-level exposure to pesticides and changes in biochemical and hematological parameters [32,34-38]. In these studies, exposed farm workers, including sprayers, were found to have lower mean hemoglobin levels, hematocrit concentrations and mean cell volumes, as well as higher mean corpuscular hemoglobin concentrations (MCHC) and platelet volumes. In addition, liver enzymes such as alkaline phosphatase, serum alanine aminotransferase, and aspartate aminotransferase were elevated in the exposed individuals compared to controls. However, esterase activities were inhibited. These parameters may be used as early biomarkers for adverse effects.

In the present study, the commonly used pesticides included organophosphorus pesticides, carbamates, pyrethroids, and dithiocarbamates. Indiscriminate use and handling of pesticides and symptomatic effects of acute exposure among male farm workers have been reported; however, data on long-term exposure to mixtures of pesticides and adverse effects among females in developing countries is lacking [9-12]. However, the present study focuses on female farm workers of reproductive age who were engaged in farming activities such as weeding and harvesting, as they are also at risk of adverse health effects. The findings from the present study add to the body of knowledge for populations exposed to low doses of pesticides through various exposure pathways.

The specific objective of this study was to describe and establish the associations between long-term, frequent exposure to pesticides and potential adverse health effects in female farm workers using hematological and serum biochemical parameters and esterase activity as biomarkers of effect. We hypothesized that long-term, frequent exposure to pesticides alters biological responses including hematological and serum biochemical parameters and esterase activity in exposed individuals. 


\section{Materials and Methods}

\subsection{Study Population and Design}

The study was conducted in two neighboring districts of the Arusha region in the north of Tanzania between September 2012 and February 2013. The exposed group was recruited from Karatu district, which produces mainly onions for both national and international markets and where the farmers use pesticides on a daily basis for protecting crops [11,39]. Mean pesticide uses in liters, spray frequency per crop and per week were 637 and 1.3, respectively, for about 270 days a year [39]. The reference population was recruited from a neighboring district-rural Arusha-where the inhabitants are mainly cattle farmers who grow vegetables for their own consumption without using pesticides. The sample size of the study population was determined using a significance level of 0.05 , a power of $80 \%$, an expected proportion with biologic parameters alterations in the reference group assumed at $40 \%$ (versus $70 \%$ in the exposed population), and a ratio of reference to exposed group of 1:2. The calculated minimum number of subjects was 93, with 30 reference and 63 exposed individuals. The study recruited 99 healthy adult females, of whom 69 were from Karatu (exposed group) and 30 were from rural Arusha (reference group). The recruited study participants were 20 years of age or older and were HIV-negative based on clinic records (a reproductive and child health card). They were living as farm workers and had been full-time residents of the study area for at least five years. The females in the exposed group were usually engaged in weeding and harvesting, whereas males did all other activities including pesticide spraying, mixing, and loading.

The study population was defined as exposed if they had resided for at least five years in Karatu, where indiscriminate pesticide use and pesticide poisoning cases were previously reported [11]. Other inclusion criteria for the exposed group included engaging in weeding and harvesting for at least three times a week and consuming vegetables and other produce from these farms. Inclusion criteria for the reference population included working with crop production and residing in rural Arusha for at least five years.

Non-pregnant females from the exposed and reference groups were recruited at reproductive and child health clinics at Askofu Hhando health center and Olturumet hospital in the Arusha region. Recruitment of study subjects was achieved with the assistance of nurses in the reproductive and child health clinics. A trained nurse identified eligible clients during attendance registration, based on the inclusion and exclusion criteria, and described the study to the potential clients. Females who agreed to participate in the study signed a written consent form.

\subsection{Questionnaire Data}

A structured questionnaire was created in English and then translated into Swahili. The questionnaire was either administered by the researcher or the local clinician. Data were collected on background characteristics such as age, education level, family income per month, occupation, tobacco smoking, drug use, and alcohol consumption. Questions were also asked about years in farm work, years of living in the study area, and names of pesticides used. Questionnaire administration was followed by a complete physical examination to check for pallor to exclude anemia, pedal edema to exclude kidney and circulatory disorder, respiratory rate and pulse rate to exclude respiratory and circulatory disorder, abdominal distension and palpation to exclude abdominal masses including kidney and liver pathology.

\subsection{Measurement of Blood Parameters}

Blood sampling and measurements were performed by specialized laboratory professionals at the service facility who had been working in the laboratory for at least five years. A sample of $5 \mathrm{~mL}$ of blood was drawn from each consenting study subject. From these $5 \mathrm{~mL}, 2 \mathrm{~mL}$ were transferred into EDTA tubes for hematological analyses. The remaining $3 \mathrm{~mL}$ of blood was centrifuged at $25^{\circ} \mathrm{C}$. Plasma was then apportioned into two different tubes, one for biochemical analysis and the other 
for esterase activity analysis. Samples for esterase enzyme activity were stored at freezing point of $-196^{\circ} \mathrm{C}$ and $-80^{\circ} \mathrm{C}$ in the field and laboratory, respectively, until analysis.

The samples for hematology were analyzed at Mt. Meru regional referral hospital hematology laboratory in Arusha using the hematological analyzer, a MS9-3H automatic full digital cell counter machine (@ 2003 Melet Schloesing Laboratories, Cergy-Pontoise, France). Samples for biochemical analysis were analyzed at the same hospital biochemistry laboratory as per CHEM 7 Erba Diagnostic Mannheim GmbH, Germany description (Quality System Certified ISO 9001 ISO 13485) for IFCC method-kinetic without pyridoxal phosphate (serum glutamic pyruvate transaminase [Sgpt], serum glutamic oxaloacetic transaminase [Sgot]), CHOD-PAP (Cholesterol) and Jaffe's method (Creatinine). The total protein concentration of each sample was determined using the Biuret Method (procedure described by Erba diagnostic Mannheim GmbH, Mannheim, Germany) at the Sokoine University of Agriculture (SUA) physiology laboratory, and esterase activity was measured in the toxicology laboratory. The procedure behind the documented fact is described by Ellman et al. (1961). We used $0.1 \mathrm{M}$ phosphate buffer ( $\mathrm{pH} 8.0), 0.075 \mathrm{M}$ acetylthiocholine iodide $(21.67 \mathrm{mg} / \mathrm{mL}$ ) substrate for AChE and S-butyrylthiocholine iodide substrate for cholinesterase variant (BChE), $0.01 \mathrm{M}$ dithiobisnitrobenzoic acid (DTNB) reagent, sodium bicarbonate, and sodium phosphate (monobasic and dibasic). The enzyme activity present in the blood plasma sample was calculated as a slope from the plot equation of linear regression [40]. Enzyme activity analysis was calculated in $\mu \mathrm{mol} / \mathrm{min} / \mathrm{mL}$ $=\Delta$ absorbance $/$ minute $\times$ total volume $($ in $\mathrm{mL}) \times 1000 / 13.6$ DTNB absorptivity $($ in $\mathrm{mM}) \times 1$ (light path in $\mathrm{cm}$ ). Activity data were expressed in $\mathrm{mM} / \mathrm{min} / \mathrm{mg}$ protein.

\subsection{Predictor and Outcome Variables}

Predictor and outcome variables were predominantly continuous. Predictor variables included age in years, height and weight, years in current occupation, and years in current residence. Outcome variables encompassing hematological parameters included white blood cell count (WBC), lymphocytes, monocytes, red blood cells, mean corpuscular volume, hematocrit, mean corpuscular hemoglobin, mean corpuscular hemoglobin concentration, and hemoglobin and platelet count. Outcome variables encompassing biochemical parameters included serum gpt and got, cholesterol and creatinine. The other outcome variable was cholinesterase activity (AChE and BChE).

\subsection{Statistical Analysis}

Subjects that had missing data were removed from the dataset before analysis. Exposed and reference groups were compared across demographic and socio-economic characteristics such as age, family income per month, and years of living in the current area using the Student's $t$ test. Comparisons between exposed and reference groups for hematological and biochemical measures were done using the two-group mean comparison sample $t$-test with unequal variances.

Bivariate and multivariate analyses were used to determine whether passive but long-term pesticide exposure was associated with abnormal cholinesterase activity or hematological and biochemical parameters. Predictor variables for linear regression models included age, body weight, family income per month, years in current occupation, and years living in the current study area. Outcome variables were the selected hematological and biochemical parameters including cholinesterase activity. The final model included predictors that had $p$-values below 0.2 in the univariate regression analysis, including age, years of living in the study area, current occupation, and body weight. The regression models were tested for fit and residual patterns using standard methods.

\subsection{Ethics Considerations}

The study obtained ethics approval from the coordinating team for National Institute for Medical Research of Tanzania. The study subjects were not sick but had attended the facility for other described reasons and no incentive was given. An informed consent was signed prior to blood sample donation 
and questionnaire administration. The health facility medical practitioner provided education first about the study.

\section{Results}

A total of 99 female subjects were included in the study, of which 69 were in the exposed group and 30 were in the reference group. Characteristics of females in the exposed and reference groups are shown in Table 1.

Table 1. Selected social and physical characteristics of study subjects in the exposed and reference groups, given as $\mathrm{n}$, mean and standard deviation (SD).

\begin{tabular}{|c|c|c|c|c|c|c|c|}
\hline \multirow{2}{*}{ Variable } & \multicolumn{3}{|c|}{ Exposed } & \multicolumn{3}{|c|}{ Reference } & \multirow{2}{*}{$p$-Value } \\
\hline & $n$ & Mean & SD & $n$ & Mean & SD & \\
\hline Age (years) & 67 & 31.2 & \pm 6.2 & 30 & 27.8 & \pm 6.3 & $<0.02$ \\
\hline Height $(\mathrm{cm})$ & 65 & 161.2 & \pm 7.5 & 27 & 162.5 & \pm 7.2 & 0.43 \\
\hline Weight $(\mathrm{kg})$ & 66 & 59.0 & \pm 9.6 & 26 & 58.3 & \pm 7.2 & 0.69 \\
\hline Years in current occupation & 52 & 12.2 & \pm 6.4 & 10 & 14.3 & \pm 5.0 & 0.26 \\
\hline Years of living in the study area & 63 & 16.8 & \pm 8.8 & 30 & 23.1 & \pm 9.2 & 0.00 \\
\hline
\end{tabular}

Age, years of living in the study area, and years in their current occupation for females in both groups were in the ranges of 18-45, 5-40, and 5-35 years, respectively (Table 1). Females in the exposed group had lived in the study area for fewer years (16.8 $\pm 8.8 ; 95 \%$ CI 14.5-18.9) and were older than females in the reference group $(23.1 \pm 9.2 ; 95 \%$ CI 19.6-26.5). There was no significant difference of family mean income Tanzanian shillings per month between the exposed $(292,173 \pm 106,769$; $95 \%$ CI $266,525-317,822 ; p=0.4)$ and reference groups $(316,666 \pm 168,325)$. The majority of all females (87\%) had at least seven years of primary education, although $13 \%$ had no formal education. Educational status was similarly low (primary level education for seven years) in both groups with more than $20 \%$ having secondary school education in exposed females (data not shown). In addition, few women (3\%) smoked and/or drank alcohol. Use of medications was not significantly different between the two groups.

The commonly applied pesticides in the study area are summarized in Table 2.

Table 2. Pesticides commonly used in the study area (Arusha region, Tanzania) and the long-term neurological and hepato-nephrotoxic adverse effects reported in animal and/or human studies.

\begin{tabular}{|c|c|c|}
\hline $\begin{array}{l}\text { Active Ingredients } \\
\text { (WHO Classification) }\end{array}$ & Common Names in the Area & Reported Effects of Repeated Exposure \\
\hline OPs: Profenofos (II) & Selecron, Profecron, Mocron, Supercron, & Neurologic disorders \\
\hline OPs: Chlorpyrifos (II) & $\begin{array}{l}\text { Dursban, Bamifos, Twigaphos, } \\
\text { Duduba, * etc. }\end{array}$ & $\begin{array}{l}\text { Persisting neurologic damage (humans); } \\
\text { changes in organ weights (e.g., liver), } \\
\text { cholinesterase enzyme inhibition, } \\
\text { developmental neurotoxicity } \\
\text { (DNA, synaptic, } \\
\text { mitotic inhibition, etc.) (animals) }\end{array}$ \\
\hline CMs: Carbosulfan (II) & Marshal, etc. & $\begin{array}{l}\text { Cholinesterase enzyme inhibition, } \\
\text { liver pathology }\end{array}$ \\
\hline $\begin{array}{l}\text { Pyrethroids (II): Permethrin, } \\
\text { lambda-cyhalothrin, deltamethrine }\end{array}$ & Ninja, Karate, Ngao, Duduba, * etc. & $\begin{array}{l}\text { Polyneuropathy and degeneration of } \\
\text { ovary (rats), sperm abnormality }\end{array}$ \\
\hline
\end{tabular}


Tables 3 and 4 show the distribution of hematological and biochemical parameters and esterase activity in the exposed and reference groups. White blood cell, lymphocyte, and platelet counts were significantly higher $(6.8 \pm 2.3,2.7 \pm 0.8,374.1 \pm 95.3)$ in the exposed group than in the reference group $(5.3 \pm 1.2,2.2 \pm 0.4,259.6 \pm 77.4)$, although all counts were within normal ranges. Mean corpuscular volume and hematocrit were significantly lower in the exposed group $(74.7 \pm 9.1,32.0 \pm 4.6)$ compared to the reference group $(84.7 \pm 7.6,36.2 \pm 4.8 ; p<0.05)$. The exposed group had higher mean levels of lymphocytes, monocytes, platelets and serum glutamic oxaloacetic acid transaminase, and serum creatinine than the reference group. Females in the exposed group had higher AChE and BChE activity than females in the reference group ( $p<0.01$ for both measures). More specifically, the BChE activity in the exposed group was four times higher than in the reference group.

Table 3. Hematological and biochemical comparisons between the exposed and reference groups.

Results are given as mean and standard deviation (SD).

\begin{tabular}{|c|c|c|c|c|}
\hline Parameter & Reference Values & $\begin{array}{c}\text { Exposed Group } \\
(n=69)\end{array}$ & $\begin{array}{c}\text { Reference Group } \\
(n=30)\end{array}$ & $p$-Value \\
\hline White blood cell count $\left({ }^{*} 0^{9} / \mathrm{L}\right)$ & $3.1-7.8$ & $6.8 \pm 2.3$ & $5.3 \pm 1.2$ & $<0.01$ \\
\hline Lymphocyte count $\left({ }^{*} 10^{9} / \mathrm{L}\right)$ & $0.9-3.75$ & $2.7 \pm 0.8$ & $2.2 \pm 0.4$ & $<0.01$ \\
\hline Monocyte count $\left(* 10^{9} / \mathrm{L}\right)$ & $0.15-0.39$ & $0.6 \pm 0.3$ & $0.4 \pm 0.6$ & 0.05 \\
\hline Red blood cell count $\left({ }^{*} 10^{12} / \mathrm{L}\right)$ & $4.07-5.13$ & $4.3 \pm 0.5$ & $4.3 \pm 0.6$ & 0.89 \\
\hline Mean corpuscular volume (MCV(fL)) & $77-94$ & $74.7 \pm 9.1$ & $84.7 \pm 7.6$ & $<0.01$ \\
\hline Haematocrit $(\%)$ & $36-45$ & $32.0 \pm 4.6$ & $36.2 \pm 4.8$ & $<0.01$ \\
\hline Mean corpuscular haemoglobin (pg) & $27.5-33.3$ & $28.1 \pm 5.4$ & $28.4 \pm 3.1$ & 0.76 \\
\hline $\begin{array}{l}\text { Mean corpuscular haemoglobin } \\
\text { concentration, } \mathrm{MCHC}(\mathrm{g} / \mathrm{dL})\end{array}$ & $33.4-37$ & $37.4 \pm 3.8$ & $33.4 \pm 1.2$ & $<0.01$ \\
\hline Haemoglobin (g/dL) & $12.4-15.5$ & $11.9 \pm 1.9$ & $12.1 \pm 1.8$ & 0.64 \\
\hline Platelet cell count $\left({ }^{*} 10^{9} / \mathrm{L}\right)$ & $150-400$ & $374.1 \pm 95.3$ & $259.6 \pm 77.4$ & $<0.01$ \\
\hline Sgpt $(\mathrm{U} / \mathrm{L})$ & up to 32 & $12.8 \pm 6.1$ & $29.5 \pm 9.9$ & $<0.01$ \\
\hline Sgot $(\mathrm{U} / \mathrm{L})$ & up to 31 & $20.7 \pm 8.9$ & $17.6 \pm 4.5$ & 0.08 \\
\hline Cholesterol (mmol/L) & $<5.2$ & $4.1 \pm 0.5$ & $4.0 \pm 1.2$ & 0.83 \\
\hline Serum creatinine $(\mu \mathrm{mol} / \mathrm{L})$ & $53.0-97.2$ & $83.9 \pm 6.6$ & $61.8 \pm 24.0$ & $<0.01$ \\
\hline
\end{tabular}

Normal range values for blacks Bain et al. [41] 1984; Tikly et al. [42] 1987. Sgpt $=$ up to $32 \mathrm{U} / \mathrm{L}$, Sgot $=$ up to $31 \mathrm{U} / \mathrm{L}$, creatinine $=53.0-97.2 \mu \mathrm{mol} / \mathrm{L}$, cholesterol $\leq 5.2 \mathrm{mmol} / \mathrm{L} .{ }^{*}$ multiplication symbol.

Table 4. Esterase enzyme activity and biochemical results comparison between the exposed and reference groups.

\begin{tabular}{ccccc}
\hline Esterase Name & Reference Values & Exposed $(\boldsymbol{n}=\mathbf{6 8})$ & Reference $(\boldsymbol{n}=\mathbf{3 0})$ & $\boldsymbol{p}$-Value \\
\hline AChE $(\mathrm{mM} / \mathrm{min} / \mathrm{mg}$ protein) & - & $0.61 \pm 0.24$ & $0.17 \pm 0.10$ \\
BChE (mM/min/mg protein) & - & $0.96 \pm 0.39$ & $0.23 \pm 0.08$ & $<0.01$ \\
Total protein concentration (g/dL) & $6.0-8.3$ & $7.4 \pm 1.2$ & $8.0 \pm 1.0$ & 0.01 \\
\hline
\end{tabular}

Multivariable regression models adjusted for age and years of living showed that females in the exposed group had significantly higher levels of both $\mathrm{AChE}$ and BChE activities ( $\beta=0.4,95 \% \mathrm{CI}$ : $0.3-0.5 ; \beta=0.7,95 \%$ CI: $0.6-0.9$, respectively) and non-significant differences for Sgot and cholesterol ( $\beta=2.0,95 \%$ CI: $5.2-9.1 ; \beta=0.4,95 \%$ CI: $0.1-0.9$, respectively) compared to females in the reference group. After adjusting the models for age and years of living in the study area, exposure status was significantly associated with Sgpt and creatinine ( $\beta=-16.3,95 \%$ CI: $22.4-10.2$; and $\beta=24.1,95 \%$ CI: 16.7-31.5 respectively).

\section{Discussion}

The results of the present study showed significant differences in biological markers between the exposed and the reference populations. Residing in an area with high pesticide applications and reported incidences of pesticide poisoning cases suggests higher exposure compared to those residing in an area with no pesticide use and no history of reported cases of pesticide poisoning. In the present study, the measures of WBC, lymphocyte, platelet counts, $\mathrm{MCHC}$, sgot and creatinine were higher in the exposed group compared to the reference group, whereas $\mathrm{MCV}$, hematocrit, hemoglobin, and sgpt were lower in the exposed group compared to the reference group. Surprisingly, the AChE and BChE activities were higher in the exposed group compared to the reference group. 
The decrease in hematocrit and MCV observed in the exposed group compared to the reference group might be explained by dehydration [36]. However, because erythrocyte deformability has been found when blood samples from healthy persons were exposed to acetylcholine in vitro, it is likely that chemicals such as pesticides with the potential to affect acetylcholine signaling may induce changes in erythrocyte size/volume [37]. Araoud et al. [32] in Tunisia and Azmi et al. [38] in Pakistan similarly found reduced MCV and hematocrit, as well as increased MCHC, WBC, lymphocyte, and platelet counts among pesticide-exposed individuals compared to controls.

The high mean platelet count observed in the exposed group compared to the reference group may be related to a primary bone marrow disorder and release of too many platelets into the blood [43]. Previous studies have observed both increased and reduced platelet turnover in both acutely and chronically pesticide-exposed individuals [32,33,43-45]. These differences across studies may result from exposure to different pesticides or mixtures of pesticides, exposure dose, and exposure frequency and time [34,46-48]. However, high platelet counts may also be secondary to other causes such as allergic reactions, cancer, diabetes, and infections $[49,50]$. The etiology behind the elevated platelet counts observed in the previous studies has not yet been established.

After adjusting for age and years of living in the study area, we observed that serum creatinine levels were significantly higher in the exposed subjects compared to reference subjects. Toe et al. [51] in Burkina Faso similarly showed high prevalence of liver and kidney dysfunction and significant associations between biochemical changes and kidney and liver function alterations in frequent users of insecticides. In addition, a study conducted in Pakistan [38] showed hematological and biochemical alterations combined with liver and kidney disorders in individuals exposed for over a month to multiple pesticides including cypermethrin, deltamethrin, polytrin, and diazninon.

In the present study, after adjusting for age and years of living in the study area, sgpt was significantly lower in the exposed subjects compared to reference subjects, and the mean value was close to the lower normal range. Low sgpt may be associated with disease conditions such as fatty liver (early), liver congestion protein deficiency, and kidney failure. Increased sgpt level is a common finding in individuals exposed to relatively high doses of pesticides [52]. However, experimental studies in rats have demonstrated that pesticide (carbendazim) exposure induces a hormesis-type $\mathrm{u}$-shaped dose response with reduced sgpt at low doses and increased sgpt at higher doses compared to controls. The changes in biochemical parameters were accompanied with histological lesions such as portal vein congestion, mononuclear cell infiltration, and hydropic degeneration of liver tissue in the test animals [53]. Reduced levels of sgpt were also found in rats exposed to diquat dibromide for four weeks [54], suggesting that various pesticides may affect sgpt differently depending on exposure conditions like dose and time.

However, as opposed to high levels, low creatinine and cholesterol levels are suggested to be of low physiological significance [55]. For all parameters-including monocyte count and sgpt level一the individual values were all close to the upper or lower reference indicating that none of references had extreme low or high values.

The significantly higher esterase activity in sera of the exposed subjects compared to the reference subjects observed in the present study was not anticipated because studies analyzing esterase activity following exposure to pesticides mainly show reduced activity [56]. However, an opposite response may be produced following long-term as opposed to acute exposure [57]. The higher esterase activity in the exposed subjects may be explained by individual tolerance due to compensatory mechanisms [58,59]. Tolerance may develop in response to long-term exposure by increasing the number of receptors and/or enzymes and/or by increasing the metabolism and excretion of chemicals [60]. Increased esterase activity following long-term exposure to different AChE inhibitors has been previously seen in rats [61,62]. Goldfish chronically exposed to sub-lethal concentrations of OPs and carbamates showed an initial significant reduction in AChE activity in the brain followed by a gradual increase over time, suggesting that adaptive mechanisms are activated under long-term exposure conditions [63]. Studies in frogs and bees support these findings. For example, 
among frogs, exposure to sub-lethal doses of a mixture of pesticides induced cross tolerance to several pesticides [64]. Likewise, increased esterase activity was also demonstrated in bees exposed to low doses of neonicotinoids (AChE inhibitors) [65]. A plausible mechanism for the increased esterase activity in bees, and potentially also in mammals, was demonstrated by Williamson et al. [66], who found upregulation of $\mathrm{AChE}$ in the brain and gut tissues of bees chronically exposed to low doses of AChE inhibiting pesticides (coumaphos, aldicarb, chlorpyrifos, and donepezil). The opposite effect on esterase activity following long-term versus short-term exposure reported in the present and previous studies may have implications for the interpretation of AChE when used as biomarker for AChE-inhibiting pesticides such as carbamates, OPs and neonicotinoids. Additionally, AChE activity in plasma recovers slowly with time after acute exposure. For example, workers who were exposed to dichlorvos showed substantial plasma cholinesterase activity inhibition, immediately after exposure, however, with time activity showed an exponential pattern of recovery with a half-life of around 12 days, and complete recovery after 50 days [67].

The AChE inhibition test is a biomarker for exposure to AChE-inhibiting pesticides, but not for other groups of pesticides, including dithiocarbamates such as Mancozeb, which are among the most used pesticides in the study area. To detect the effects of exposure to multiple pesticides that may affect various tissues, organs and body systems, new biomarkers should be identified. Pesticides such as Mancozeb and Endosulfan, which are commonly used in mixture with OPs in the study area, may potentially add to the adverse effects among chronically exposed individuals.

Several limitations of the present study should be noted. Because of limited resources, we had to restrict the number of participants to 99 , which may have reduced the statistical power and consequently lead to lack of external validity. In addition, the use of a cross-sectional design makes it difficult to ascertain a causal link. Furthermore, while bio-monitoring for specific pesticides is a more sensitive method for measuring exposure, this could not be used in the present study because of resource constraints as well as rapid metabolism and excretion from the body.

The methods used to assess exposure were not optimal to identify the individual exposure levels. However, in addition to the information given by the study participants, the significant difference in pesticide use between the two districts is well documented in scientific reports [11,39] and from pesticide dealers in the districts. Furthermore, the selection of participants was based on clear inclusion criteria defining exposure status and levels. This study is unique because it is reporting on a vulnerable but not institutionally protected group of female farm workers that has been scantly studied. Conducting a study in a hospital setting where privacy, care, and confidentiality are assured is thought to improve reliability and validity of the findings. Furthermore, regression methods were applied for analysis to control for potential confounders $[68,69]$. Despite the discussed limitations, the present findings are important for establishing risk of long-term exposure to mixtures of pesticides and establishing a relevant hypothesis for further investigation.

\section{Conclusions}

The results of the present study showed significant biological, biochemical, and esterase activity differences between the exposed and reference groups, suggesting higher risk of adverse health effects in the pesticide-exposed individuals. Identification of relevant biomarkers of exposure and effect in individuals chronically exposed to pesticides is important for diagnostic and preventive measures. Studies in vulnerable populations such as children and pregnant women exposed to harmful chemicals like pesticides are important. Further studies should assess the prevalence of pesticide-induced diseases in the exposed vulnerable study population.

Acknowledgments: This study received financial support from the Research Council of Norway (NFR nr: 204051). We are grateful to Mzumbe University, and MORATANZ project that financially supported the abroad training on data management and epidemiology in Norway. We also express our gratitude to all that willingly consented to participate in the study and to donate a blood sample for analysis, as well as village executives from Mang'ola for their orientation and facilitation to obtain health facility in-charges. We are so grateful to District Executive Director, Clement Berege; District Medical Officer, Lucas Kazingo (Karatu, Arusha); District Medical Officer, 
Nkina Thobius (Arusha rural); and Mwajabu Mazina Mbaga at Olturumet District Hospital for granting permission that facilitated the study in their respective districts. We especially thank Peter Sulle, Matron Ruth Mathias, Jose Angular, and Udaya Gorge for clinical and administrative support at Askofu Hhando health facility. We would also like to thank the laboratory technicians, Michael Kirway, Emmanuel, Irene, and L. Lyaruu, who facilitated the blood sampling and acquisition of reagents for hematological and biochemical sample analysis. Special thanks go to King'weng'wetta R. Bunini for questionnaire data entry into MS Excel parallel to the second entrant (researcher). We also thank Christen Said as a native English speaker from University of California, San Francisco (UCSF) for grammatical corrections to the final revised version of this manuscript. Finally, we would like to acknowledge the Medical Research Coordinating Committee of the National Institute for Medical Research for granting ethical approval to carry out and to publish the results of this study (Ref NIMR/HQ/R.8a/Vol.IX/1354 and NIMR/HQ/P.12 VOL XV/7, respectively).

Author Contributions: A number of people and institutions contributed to the success of this work at different levels and sections as expanded in the acknowledgement. Robinson Hammerton Mdegela contributed in the study design including the conduct of laboratory procedures, proposal development, and critical review of laboratory work. Rudovick Kazwala, Hezron Nonga, Mette Muller, Elisabeth Lie contributed in designing the study, reviewing the manuscript, and commenting. Eystein Skjerve contributed from the study design to data analysis training and technical support of data analysis including critical review of the manuscript, and reporting on as well as approval of the manuscript. Jan Ludvig Lyche contributed at all stages from study design, several critical reviews of the manuscript, and approval of the final manuscript as the main supervisor.

Conflicts of Interest: The authors declare no conflict of interest.

\section{References}

1. Tanzania Mainland Poverty Assessment. Available online: http://www.worldbank.org/content/dam/ Worldbank.web.pdf (accessed on 3 December 2015).

2. Children's Health and the Environment: WHO Training Package for the Health Sector. Available online: http://www.who.int/ceh/capacity/Pesticides.pdf (accessed on 3 December 2015).

3. Pesticide and Poverty a Case Study on Trade and Utilization of Pesticides in Tanzania: Implication to Stockpiling. Available online: http://www.pan-uk.org/archive/Projects.pdf (accessed on 3 December 2015).

4. Mancini, F.; Van Bruggen, A.H.; Jiggins, J.L.; Ambatipudi, A.C.; Murphy, H. Acute pesticide poisoning among female and male cotton growers in India. Int. J. Occup. Environ. Health 2005, 11, 221-232. [CrossRef] [PubMed]

5. Jensen, H.K.; Konradsen, F.; Jors, E.; Petersen, J.H.; Dalsgaard, A. Pesticide use and self-reported symptoms of acute pesticide poisoning among aquatic farm workers in Phnom Penh, Cambodia. J. Toxicol. 2011, 2011. [CrossRef]

6. Mancini, F.; Jiggins, J.L.; O'Malley, M. Reducing the incidence of acute pesticide poisoning by educating farm workers on integrated pest management in South India. Int. J. Occup. Environ. Health 2009, 15, 143-151. [CrossRef] [PubMed]

7. Mbakaya, C.F.; Ohayo-Mitoko, G.J.; Ngowi, V.A.; Mbabazi, R.; Simwa, J.M.; Maeda, D.N.; Stephens, J.; Hakuza, H. The status of pesticide usage in East Africa. Afr. J. Health Sci. 1994, 1, 37-41. [PubMed]

8. Food and Agriculture Organization of the United Nations (FAO). Review of Pollution in the African Aquatic Environment; CIFA Technical Paper 25; Calamari, D., Naeve, H., Eds.; Food and Agriculture Organization of the United Nations: Rome, Italy, 1994; p. 118.

9. Ngowi, A.V.; Maeda, D.N.; Partanen, T.J.; Sanga, M.P.; Mbise, G. Acute health effects of organophosphorus pesticides on Tanzanian small-scale coffee growers. J. Expo. Anal. Environ. Epidemiol. 2001, 11, 335-339. [CrossRef] [PubMed]

10. Ngowi, A.V.; Maeda, D.N.; Wesseling, C.; Partanen, T.J.; Sanga, M.P.; Mbise, G. Pesticide-handling practices in agriculture in Tanzania: Observational data from 27 coffee and cotton farms. Int. J. Occup. Environ. Health 2001, 7, 326-332. [CrossRef] [PubMed]

11. Ngowi, A.V.; Mbise, T.J.; Ijani, A.S.M.; London, L.; Ajayi, O.C. Pesticides use by smallholder farm workers in vegetable production in Northern Tanzania. Crop Prot. 2007, 26, 1617-1624. [CrossRef] [PubMed]

12. Ngowi, A.V.; Maeda, D.N.; Partanen, T.J. Knowledge, attitudes and practices (KAP) among agricultural extension workers concerning the reduction of the adverse impact of pesticides in agricultural areas in Tanzania. Med. Lav. 2002, 93, 338-346. [PubMed]

13. Azaroff, L.S.; Neas, L.M. Acute health effects associated with nonoccupational pesticide exposure in rural El Salvador. Environ. Res. 1999, 80, 158-164. [CrossRef] [PubMed] 
14. Kamel, F.; Hoppin, J.A. Association of pesticide exposure with neurologic dysfunction and disease. Environ. Health Perspect. 2004, 112, 950-958. [CrossRef] [PubMed]

15. Mnif, W.; Hassine, A.I.; Bouaziz, A.; Bartegi, A.; Thomas, O.; Roig, B. Effect of endocrine disruptor pesticides: A review. Int. J. Environ. Res. Public Health 2011, 8, 2265-2303. [CrossRef] [PubMed]

16. Bjorling-Poulsen, M.; Andersen, H.R.; Grandjean, P. Potential developmental neurotoxicity of pesticides used in Europe. Environ. Health 2008, 7. [CrossRef] [PubMed]

17. Schreck, E.; Geret, F.; Gontier, L.; Treilhou, M. Neurotoxic effect and metabolic responses induced by a mixture of six pesticides on the earthworm Aporrectodea caliginosa nocturna. Chemosphere 2008, 71, 1832-1839. [CrossRef] [PubMed]

18. Jokanovic, M.; Kosanovic, M. Neurotoxic effects in patients poisoned with organophosphorus pesticides. Environ. Toxicol. Pharmacol. 2010, 29, 195-201. [CrossRef] [PubMed]

19. Jett, D.A. Neurotoxic pesticides and neurologic effects. Neurol. Clin. 2011, 29, 667-677. [CrossRef] [PubMed]

20. Petrelli, G.; Figa-Talamanca, I.; Lauria, L.; Mantovani, A. Spontaneous abortion in spouses of greenhouse workers exposed to pesticides. Environ. Health Prev. Med. 2003, 8, 77-81. [CrossRef] [PubMed]

21. Arbuckle, T.E.; Lin, Z.; Mery, L.S. An exploratory analysis of the effect of pesticide exposure on the risk of spontaneous abortion in an Ontario farm population. Environ. Health Perspect. 2001, 109, 851-857. [CrossRef] [PubMed]

22. Sanborn, M.; Kerr, K.J.; Sanin, L.H.; Cole, D.C.; Bassil, K.L.; Vakil, C. Non-cancer health effects of pesticides: Systematic review and implications for family doctors. Can. Fam. Physician 2007, 53, 1712-1720. [PubMed]

23. Smith, J.L.; Garry, V.F.; Rademaker, A.W.; Martin, R.H. Human sperm aneuploidy after exposure to pesticides. Mol. Reprod. Dev. 2004, 67, 353-359. [CrossRef] [PubMed]

24. Patil, J.A.; Patil, A.J.; Govindwar, S.P. Biochemical effects of various pesticides on sprayers of grape gardens. Indian J. Clin. Biochem. 2003, 18, 16-22. [CrossRef] [PubMed]

25. Dzul-Caamal, R.; Dminguez-Lopez, M.L.; García-Latorre, E.; Vega-López, A. Implications of cytochrome 450 isoenzymes, aryl-esterase and oxonase activity in the inhibition of the acetylcholinesterase of Chirostoma jordani treated with phosphorothionate pesticides. Ecotoxicol. Environ. Saf. 2012, 84, 199-206. [CrossRef] [PubMed]

26. Handal, A.J.; Lozoff, B.; Breilh, J.; Harlow, S.D. Neurobehavioural development in children with potential exposure to pesticides. Epidemiology 2007, 18, 312-320. [CrossRef] [PubMed]

27. Bouchard, M.F.; Chevrier, J.; Harley, K.G.; Kogut, K.; Vedar, M.; Calderon, N.; Trujillo, C.; Johnson, C.; Bradman, A.; Barr, D.B.; et al. Prenatal exposure to organophosphate pesticides and IQ in 7-year-old children. Environ. Health Perspect. 2011, 119, 1189-1195. [CrossRef] [PubMed]

28. Rastogi, S.K.; Tripathi, S.; Ravishanker, D. A study of neurologic symptoms on exposure to organophosphate pesticides in the children of agricultural workers. Indian J. Occup. Environ. Med. 2010, 14, 54-57. [CrossRef] [PubMed]

29. Hohenadel, K.; Harris, S.A.; McLaughlin, J.R.; Spinelli, J.J.; Pahwa, P.; Dosman, J.A.; Demers, P.A.; Blair, A. Exposure to multiple pesticides and risk of non-Hodgkin lymphoma in men from six Canadian provinces. Int. J. Environ. Res. Public Health 2011, 8, 2320-2330. [CrossRef] [PubMed]

30. Lionetto, M.G.; Caricato, R.; Calisi, A.; Giordano, M.E.; Schettino, T. Acetylcholinesterase as a Biomarker in Environmental and Occupational Medicine: New Insights and Future Perspectives. Biomed. Res. Int. 2013, 2013. [CrossRef] [PubMed]

31. Brock, A. Inter and intra individual variations in plasma cholinesterase activity and substance concentration in employees of an organophosphorus insecticide factory. Br. J. Ind. Med. 1991, 48, 562-567. [PubMed]

32. Araoud, M.; Neffeti, F.; Douki, W.; Hfaiedh, H.B.; Akrout, M.; Hassine, M.; Najjar, M.F.; Kenani, A. Adverse effects of pesticides on biochemical and haematological parameters in Tunisian agricultural workers. J. Expo. Sci. Environ. Epidemiol. 2012, 22, 243-247. [CrossRef] [PubMed]

33. Payan-Renteria, R.; Garibay-Chavez, G.; Rangel-Ascencio, R.; Preciado-Martínez, V.; Muñoz-Islas, L.; Beltrán-Miranda, C.; Mena-Munguía, S.; Jave-Suárez, L.; Feria-Velasco, A.; De Celis, R. Effect of chronic pesticide exposure in farm workers of a Mexico community. Arch. Environ. Occup. Health 2012, 67, 22-30. [CrossRef] [PubMed]

34. Hu, R.; Huang, X.; Huang, J.; Li, Y.; Zhang, C.; Yin, Y.; Chen, Z.; Jin, Y.; Cai, J.; Cui, F. Long- and short-term health effects of pesticide exposure: A cohort study from China. PLoS ONE 2015, 10. [CrossRef] [PubMed] 
35. Fareed, M.; Pathak, M.K.; Bihari, V.; Kamal, R.; Srivastava, A.K.; Kesavachandran, C.N. Adverse respiratory health and hematological alterations among agricultural workers occupationally exposed to organophosphate pesticides: A cross-sectional study in North India. PLoS ONE 2013, 8. [CrossRef]

36. Demos, K.; Sazakli, E.; Jelastopulu, E.; Charokopos, N.; Ellul, J.; Leotsinidis, M. Does farming have an effect on health status? A comparison study in West Greece. Int. J. Res. Public Health 2013, 10, 776-792. [CrossRef] [PubMed]

37. Mesquita, R.; Pires, I.; Saldanha, C.; Martins-Silva, J. Effects of acetylcholine and spermineNONOate on erythrocyte hemorheologic and oxygen carrying properties. Clin. Hemorheol. Microcirc. 2001, 25, 153-163. [PubMed]

38. Azmi, M.A.; Naqvi, S.N.; Akhtar, K.; Moinuddin; Parveen, S.; Parveen, R.; Aslam, M. Effect of pesticide residues on health and blood parameters of farm workers from rural Gadap, Karachi, Pakistan. J. Environ. Biol. 2009, 30, 747-756. [PubMed]

39. Manyilizu, W.B.; Mdegela, R.H.; Kazwala, R.; Müller, M.; Lyche, J.L.; Skjerve, E. Self-reported Health Effects among Short and Long-term Pesticide Sprayers in Arusha, Northern Tanzania: A cross Sectional Study. Occup. Med. Health Aff. 2015, 3. [CrossRef]

40. Rickwood, C.J.; Galloway, T.S. Acetylcholinesterase inhibition as a biomarker of adverse effect: A study of Mytilus edulis exposed to the priority pollutant chlorfenvinphos. Aquatic Toxicol. 2004, 67, 45-56.

41. Bain, B.; Seed, M.; Godsl, I. Normal values for peripheral blood white cell counts in women of four different ethnic origins. J. Clin. Pathol. 1984, 37, 188-193. [CrossRef] [PubMed]

42. Tikly, M.; Blumsohn, D.; Solomons, H.D.; Govender, Y.; Atkinson, P.M. Normal haematological reference values in the adult black population of the Witwatersrand. SAMJ 1987, 72, 135-136. [PubMed]

43. Deutsch, V.R.; Tomer, A. Megakaryocyte development and platelet production. Br. J. Haematol. 2006, 134, 453-466. [CrossRef] [PubMed]

44. García-García, C.R.; Parrón, T.; Requena, M.; Alarcón, R.; Tsatsakis, A.M.; Hernández, A.F. Occupational pesticide exposure and adverse health effects at the clinical, hematological and biochemical level. Life Sci. 2016, 145, 274-283. [CrossRef] [PubMed]

45. Khan, A.A.; Shah, M.A.; Rahman, S.U. Occupational exposure to pesticides and its effects on health status of workers in Swat, Khyber Pakhtunkhwa, Pakistan. J. Biol. Life Sci. 2013, 4, 43-55. [CrossRef]

46. Rastogi, S.K.; Satyanarayan, P.V.; Ravishankar, D.; Tripathi, S. A study on oxidative stress and antioxidant status of agricultural workers exposed to organophosphorus insecticides during spraying. Indian J. Occup. Environ. Med. 2009, 3, 131-134. [CrossRef] [PubMed]

47. Silins, I.; Högberg, J. Combined Toxic Exposures and Human Health: Biomarkers of Exposure and Effect. Int. J. Environ. Res. Public Health 2011, 8, 629-647. [CrossRef] [PubMed]

48. Wafa, T.; Nadia, K.; Amel, N.; Ikbal, C.; Insaf, T.; Asma, K.; Hedi, M.A.; Mohamed, H. Oxidative stress, hematological and biochemical alterations in farmers exposed to pesticides. J. Environ. Sci. Health B 2013, 48, 1058-1069. [CrossRef] [PubMed]

49. Kujovich, J.L. Hemostatic defects in end stage liver disease. Crit. Care Clin. 2005, 21, 563-587. [CrossRef] [PubMed]

50. Angiolillo, D.J.; Fernandez-Ortiz, A.; Bernardo, E.; Ramírez, C.; Sabaté, M.; Jimenez-Quevedo, P.; Hernández, R.; Moreno, R.; Escaned, J.; Alfonso, F.; et al. Platelet function profiles in patients with type 2 diabetes and coronary artery disease on combined Aspirin and Clopidogrel Treatment. Diabetes 2005, 54, 2430-2435. [CrossRef] [PubMed]

51. Toe, A.M.; Ilboudo, S.; Ouedraogo, M.; Guissou, P.I. Biological alterations and self-reported symptoms among insecticides-exposed workers in Burkina Faso. Interdiscip. Toxicol. 2012, 5, 42-46. [CrossRef] [PubMed]

52. Patil, J.A.; Patil, A.J.; Sontakke, A.V.; Govindwar, S.P. Occupational pesticides exposure of sprayers of grape gardens in western Maharashtra (India): Effects on liver and kidney function. J. Basic Clin. Physiol. Pharmacol. 2009, 20, 335-355. [CrossRef] [PubMed]

53. Muthuviveganandavel, V.; Muthuraman, P.; Muthu, S.; Srikumar, K. Toxic effects of carbendazim at low dose levels in male rats. Toxicol. Sci. 2008, 33, 25-30. [CrossRef]

54. Diquat Dibromide Risk Characterization Document (17 August 1994). Available online: http://www.cdpr. ca.gov/docs/risk/rcd/-diquat.pdf (accessed on 3 December 2015).

55. Interpretation of Lab Test Profiles. Available online: http://web2.airmail.net/uthman/lab_test.html (accessed on 3 December 2015). 
56. Dhananjayan, V. Organochlorine pesticides and polychlorinated biphenyls in various tissues of waterbirds in Nalabana bird sanctuary, Chilika Lake, Orissa, India. Bull. Environ. Contam. Toxicol. 2012, 89, 197-201. [CrossRef] [PubMed]

57. Trevisan, R.; Uliano-Silva, M.; Pandolfo, P.; Franco, J.L.; Brocardo, P.S.; Santos, A.R.; Farina, M.; Rodrigues, A.L.; Takahashi, R.N.; Dafre, A.L. Antioxidant and acetylcholinesterase response to repeated malathion exposure in rat cerebral cortex and hippocampus. Basic Clin. Pharmacol. Toxicol. 2012, 102, 365-369. [CrossRef] [PubMed]

58. Costa, L.G.; Schwab, B.W.; Murphy, S.D. Tolerance to anticholinesterase compounds in mammals. Toxicology 1982, 25, 79-97. [CrossRef]

59. Salvi, R.M.; Lara, D.R.; Ghisolfi, E.S.; Portel, L.V.; Dia, R.D.; Souza, D.O. Neuropsychiatric evaluation in subjects chronicaly exposed to organophosphate pesticides. Toxicol. Sci. 2003, 72, 267-271. [CrossRef] [PubMed]

60. Ray, D.E. Chronic effects of low level exposure to anticholinesterases: A mechanistic review. Toxicol. Lett. 1998, 103, 527-533. [CrossRef]

61. Gupta, R.C.; Patterson, G.T.; Dettbarn, W.D. Mechanisms involved in the development of tolerance to DFP toxicity. Fundam. Appl. Toxicol. 1985, 5, S17-S28. [CrossRef]

62. Yang, Z.P.; Dettbarn, W.D. Prevention of tolerance to the organophosphorus anticholinesterase paraoxon with carboxylesterase inhibitors. Biochem. Pharmacol. 1998, 55, 1419-1426. [CrossRef]

63. Ferrari, A.; Venturino, A.; de D'Angelo, A.M. Time course of brain cholinesterase inhibition and recovery following acute and subacute azinphosmethyl, parathion and carbaryl exposure in the goldfish (Carassius auratus). Ecotoxicol. Environ. Saf. 2004, 57, 420-425. [CrossRef]

64. Hua, J.; Jones, D.K.; Relyea, R.A. Induced tolerance from a sublethal insecticide leads to cross-tolerance to other insecticides. Environ. Sci. Technol. 2014, 48, 4078-4085. [CrossRef] [PubMed]

65. Samson-Robert, O.; Labrie, G.; Mercier, P.; Chagnon, M.; Derome, N.; Fournier, V. Increased Acetylcholinesterase Expression in Bumble Bees During Neonicotinoid-Coated Corn Sowing. Sci. Rep. 2015, 5. [CrossRef] [PubMed]

66. Williamson, S.M.; Moffat, C.; Gomersall, M.A.; Saranzewa, N.; Connolly, C.N.; Wright, G.A. Exposure to acetylcholinesterase inhibitors alters the physiology and motor function of honeybees. Front. Physiol. 2013, 4. [CrossRef] [PubMed]

67. Mason, H.J. The recovery of plasma cholinesterase and erythrocyte acetylcholinesterase activity in workers after over-exposure to dichlorvos. Occup. Med. 2000, 50, 343-347. [CrossRef]

68. Pearce, N.; Checkoway, H.; Kriebel, D. Bias in occupational epidemiology studies. Occup. Environ. Med. 2007, 64, 562-568. [CrossRef] [PubMed]

69. Dohoo, I.; Martin, W.; Stryhn, H. Methods in Epidemiologic Research, 2nd ed.; McPike, S.M., Ed.; Ver Inc.: Charlottetown, PE, Canada, 2012.

(C) 2016 by the authors; licensee MDPI, Basel, Switzerland. This article is an open access article distributed under the terms and conditions of the Creative Commons Attribution (CC-BY) license (http://creativecommons.org/licenses/by/4.0/). 